\title{
A Study of Young Customers' Preferences for Bank Selection in Pakistan
}

\author{
Ahmad Kaleem and Rahmatullah \\ COMSATS IIT and University of Management and Technology \\ Lahore, Pakistan
}

\begin{abstract}
:
This article focuses on the priorities and selection criteria employed by the young customers who are the consumers of today and prospective buyers in future. The students from the leading institution of Pakistan (University of Management and Technology (UMT)) based in Lahore, are selected for this study representing the young customers. A sample of three hundred respondents $(66 \%$ male and $34 \%$ female) out of three thousand total populations was selected. The analysis of their responses relied on 23 factors (16 for general banking and 7 for Islamic banking) extracted from the relevant literature, interviews with banking experts, and college students. The findings reveal that major factors determining the priorities and selection criteria of a bank's are: better services or speed of transaction, friendliness of staff, ATMs, locality convenience, reputation, and low services charges. In case of Islamic banking, the respondents show full confidence on its competitiveness. They also show strong desire to open accounts with Islamic banks and to make their contribution in its progress.
\end{abstract}

\section{INTRODUCTION}

Commercial banks are the main sources of funds in Pakistan. Being home of 43 commercial banks, with 7352 branches and Rs 606,926 million (U.S \$ 10,500 millions) of deposits, (Pakistan statistical year book, 2003), the country has a vast potential of growth in financial activities. The management of the commercial banks must know their customers' selection criteria and expectations in order to explore and design appropriate market strategies. They must understand how individuals or groups belonging to different segments select their banks. Yet, young customers (i.e. university students) are the one promising segment, which arguably, have not been given enough attention.

This survey designs to discover the bank selection parameters employed by young customers in Pakistan. The segment represents sizeable portion of country's population which is growing at the rate of 2.8 percent per annum. Students from University of Management and Technology, Lahore, are being employed as young customers. They can be proved as potential future clients once they enter in practical life where salaries are normally drawn through cheques or employees' bank accounts. Recently two of the commercial banks in Bahrain launched new savings accounts for young customers: National Bank of Bahrain launched an account on November 24, 1999 called "Save Wave", and Hong Kong Shanghai Banking Corporation (formerly named the
British Bank of the Middle East) launched an account on January 21, 2000 named "Head Start" (Almossivi, 2001) [1].

The survey also covers the young customers' perceptions towards Islamic banking. The issue is important in a country like Pakistan where the Central Bank encourage Islamic banking system to operate parallel to conventional banking system. The growing competition in terms of products and services has made increasingly vital for banks to identify the factors that determine the basis upon which young customers select among financial services providers.

In many countries, great deals of research efforts have been expended to investigate bank selection criteria for young customers (Almossivi (2001) [1], Edris (1997) in Kuwait [2], Frimpong (1999) in Ghana [3], Kaynak, Küçükemiroglu and Odabasi (1991) in Turkey [4], Radi (1989) [5]). This study investigates the students' perception towards bank selection criteria in case of Pakistan. The results would help banks to identify the appropriate marketing strategies needed to attract new young customers and to retain the existing ones.

The objectives of this study can be defined as follows:

1. To determine the product/service characteristics that young customers consider important while selecting a bank and how these characteristics can be prioritized according to their importance.

2. To determine the young customers' preference towards Islamic banking and the managerial implications of overall results for decision making.

3. To examine the role of individual differences such as qualification level, gender, and age on the overall perceived usefulness of the services offered.

\section{LITERATURE REVIEW}

The customers' priorities towards the selection of banks have been extensively explored in banking literature. Numbers of studies have analyzed the factors, which interprets the selection criteria used by young customers. Frimpong (1999) [3] observed that the Ghanaian customers choose banks based on convenient location followed by high rates of interest and low services charges. The customers are resistant to long-term investments and the most effective media that best inform customers are word-of-mouth, radio, and television.

Research of Burc Ülengin (1998) [6] revealed that young customers in Germany prefer the extended loyalty 
programs, the continuous information flow from the bank, the ATMs, the maximum five-minutes waiting time in the branches, and simple application procedures for all types of accounts. In terms of higher-order decision constructs, delivery channels, and customer relations have the strongest influence on the respondents' preferences. The research suggests that hierarchical information integration may be a potentially useful method for bank management to study complex decision-making problems such as bank choice.

Mosad Zineldin (1996) [7] found that a well-integrated application of technology encourages customers to use a whole range of banking products/services rather than just a few. An efficient application of technology also helps to build loyalty by creating deeper and fuller customer relationships. Mosad observed that in case of Swedish market the functional quality has more impact on bank selection than traditional marketing activities such as convenience of location, price, and advertising. Teik (1999) [8], in case of Singapore, found that the respondents with different demographic characteristics select banks differently. Location convenience was found to be not an important criterion in the bank selection process. The availability of ATMs services was also found to be the most important bank selection criterion.

Researchers have also argued that increasing customers' loyalty helps banks to create future revenues. Andreson, Fomell and Lehmann (1994) [9], when investigating over 25,000 customers of 77 Swedish organizations in a variety of industries noted that the firms with higher reported satisfaction levels also show significantly higher returns. They say an annual $1 \%$ increase in customer satisfaction worth $11.4 \%$ improvement in current return on investment.

The study made by Baldrigeplus (1999) [10] reveals four factors that he considers vital in customer service. These factors are relationship closeness, competitive fees and charges, listening to the needs of the customer, and 'value' (quality of service, taking into account fees and charges). The top and bottom performing banks scored significantly differently for all factors that clearly separate the best from the worst. The study does not imply factor like 'friendliness of staff', as important variable.

Another research conducted in Canada by Kaynak (1986) divided his sample into two groups; bank customers, and bank managers. These two groups were asked the same question, "What is the most ideal bank according to your perception?" Bank customers preferred a bank with 'fast and efficient services', while managers choose 'reputation' as the main factor.

Bank-customer relationship is not only confining to conventional banks. Many studies have also been appeared in case of Islamic banks which represent globally through more than 8000 branches with estimated assets of U.S \$ 170 billion (Jamal and Khalid, 1999) [11]. Many large international banks also offer Islamic banking products.
For instance, Citibank has established branches in many countries to operate in accordance with Islamic Sharia'h (law) principles. The study made by Almossawi (2001) [1], in case of Islamic and conventional banking in Jordan, concluded that young customers place more emphasis on factors like a bank's reputation, availability of parking space, friendliness of bank personnel, and 24-hours availability of ATMs services at convenient locations. Almossavi also found that majority of the respondents are satisfied with most aspects of the Islamic bank's products and services. Islamic banking in Jordan is currently enjoying competitive advantage in terms of customer confidence.

Radi (1989) [5] concluded that religion is not the only motive behind depositing money in Islamic banks. The customers also considered the returns on deposits before investing money with Islamic banks. The results also found opening of new branches, increase utilizations of services provided, and peer group influence play an important role in selecting Islamic banks as depository institutions. Interestingly, his study also found that the bank customers have high degree of awareness towards the profit-loss-sharing modes of investment and of the economic and social development role of the Islamic banking system

\section{STUDY SAMPLE AND DATA COLLECTION PROCESS}

The study selects 300 students out of total population of 3000 from the University of Management and Technology, representing 10 percent (66\% male and $34 \%$ female). Students were selected based on the required criteria: being young and being potential bank customers of today and in future as well. The required data were collected through a specially designed questionnaire. The questionnaires were passed to respondents and received back simultaneously by hand. Therefore, 230 completed questionnaires out of 300 were easily received. The response rate was $77 \%$ which is quite satisfactory. Thirty carelessly filled questionnaires were rejected to further improve the quality and strength of data.

The questionnaire was divided into two parts. The first part contained sixteen factors to cover various aspects of general banking to know the customers' priorities. The second part consisted on seven factors regarding Islamic banking to discover the young customers' views and their perception towards Islamic banking. The factors were adapted from the relevant literature, personal experience, interviews with various local bank officials, and students of the UMT (Pakistan). In answering the questions, respondents were assured of the confidentiality of their responses and their names were not solicited. All questions were asked on five-point Likert scale, ranging 1 for "not important at all" to 5 for "very important". 
The profiles of the personal characteristics of the sample population are outlined in table 1. The two groups in education-based classification are, under graduates $(64.0 \%)$ and master degree program $(36.0 \%)$. The data also shows that $67.5 \%$ of the respondents are between 21 and 25 years old. Almost $66.0 \%$ of the respondents are male while females account for only $34.0 \%$. This may be due to the nature of society where males normally join the professional institutions. More than half $(56.0 \%)$ of the sample respondents already have the bank accounts.

Table 1: Respondents' Profile

\begin{tabular}{|l|c|c|}
\hline & Frequency & Percentage \\
\hline Qualification & & \\
Bachelor & 128 & 64.0 \\
Master & 72 & 36.0 \\
\hline Gender & 132 & 66.0 \\
Male & 68 & 34.0 \\
Female & & \\
\hline Age & 46 & 23.0 \\
$17-20$ & 135 & 67.5 \\
$21-25$ & 19 & 9.5 \\
$26->$ & & \\
\hline A/c Holder & 112 & 56.0 \\
Yes & 88 & 44.0 \\
No & \\
\hline
\end{tabular}

\section{ANALYSIS RESULTS}

Table 2 presents the results that have been categorized according to the mean scores that each factor obtains. Three factors score more than four marks in the mean ranking analysis. The findings reveal that youngsters/students in Pakistan give much emphasis to "fast and efficient counter service" followed by "speed of transaction" and then "friendliness of bank staff." The results are quite similar to Kaynak (1986) who found that customers gave more preferences to fast and efficient counter services in case of Canada. The youngsters of today also seek friendly environment and like to establish acquaintance with their respective bank. They are more dynamic and enthusiastic and want to be treated differently.

Table 2: Young Customer's Priorities towards General Banking

\begin{tabular}{|c|c|c|c|}
\hline Statement & Mean & Percentage & Rank \\
\hline Fast and efficient counter services & 4.23 & 84.50 & 1 \\
\hline Speed of transactions & 4.10 & 82.00 & 2 \\
\hline Friendliness of bank staff & 4.09 & 81.80 & 3 \\
\hline Knowledgeable about your requirements & 3.97 & 79.30 & 4 \\
\hline Availability of ATM & 3.90 & 77.90 & 5 \\
\hline Impression of staff and manager & 3.88 & 77.50 & 6 \\
\hline Low services charges & 3.86 & 77.10 & 7 \\
\hline Reputation and image of a bank & 3.85 & 77.00 & 8 \\
\hline Parking facilities and convenience of location & 3.84 & 76.70 & 9 \\
\hline Hours of operation & 3.81 & 76.20 & 10 \\
\hline Online banking & 3.70 & 74.00 & 11 \\
\hline Interior comforts (like air conditioner) & 3.57 & 71.30 & 12 \\
\hline Higher profits on account & 3.43 & 68.50 & 13 \\
\hline External appearance of bank & 3.36 & 67.20 & 14 \\
\hline Mass media advertisement & 3.26 & 65.20 & 15 \\
\hline Recommendations by friends and relatives & 3.17 & 63.30 & 16 \\
\hline
\end{tabular}

Journal of Independent Studies and Research (JISR)

Volume 3, Number 1, January 2005
The next influential factors that acquire the mean score more than 3.85 but less than 4.00 are "knowledge about your requirements, availability of ATM, impression of staff, and low service charges." The findings interpret the changing trend towards the modernization. The young customers want their banks to be well aware about their necessities and the services they require. They also consider the image of the staff and the overall reputation before depositing money. There is also an increasing trend towards the usage of ATMs. The youngsters want to get themselves freed from all the sanctions in terms of: limited banking hours, location of the branch or any inconvenience in encashment. The young customers also have economical behavior of thinking. They do not want to pay lot of encashment charges. It means, this segment can be attracted by low services charges.

The young customers give importance to the "reputation and image of a bank, parking facilities, convenience of location, banking operations hours, online banking and interior comfort." These factors acquire less then 3.86 but more then 3.5 mean scores. In this group the most important and high scored factor is reputation and image of a bank. The young customers consider overall image before selecting a bank since it will reflect the safety of ones funds. The mean scores further conclude that the youngsters/students want to save their time and also desire to use latest electronic facilities being adopted anywhere in the world. In other word, they fully understand the importance of high technological facilities in their lives.

The last four factors, which young costumers consider least important, score mean values less than 3.5. Interestingly, the respondents show little concern with high rate of profit. It is possibly due to their youth age and less financial responsibility currently on their shoulders. The young students also do not consider the media advertisement and give least importance to others' recommendations. They want to make decision by their own based on personal experiences. 
Table 3: Chi Square Test

\begin{tabular}{|l|c|c|c|c|c|c|}
\hline \multirow{2}{*}{\multicolumn{1}{|c|}{ Statements }} & \multicolumn{2}{c|}{ Qualification } & \multicolumn{2}{c|}{ Age } & \multicolumn{2}{c|}{ Gender } \\
\cline { 2 - 7 } & Chi-sq & Sig & Chi-sq & Sig & Chi-sq & Sig \\
\hline 1-Fast and efficient counter services & 3.23 & 0.20 & 2.05 & 0.56 & 0.53 & 0.47 \\
\hline 2-Speed of transactions & 2.00 & 0.37 & 2.06 & 0.56 & 1.00 & 0.32 \\
\hline 3-Friendliness of bank staff & 4.20 & 0.12 & 4.72 & 0.19 & 0.92 & 0.34 \\
\hline 4-Knowledgeable about your requirements & $\mathbf{7 . 1 7}$ & $\mathbf{0 . 0 3}$ & 1.49 & 0.69 & 2.22 & 0.14 \\
\hline 5-Availability of ATM & 0.94 & 0.63 & 4.67 & 0.20 & 0.31 & 0.58 \\
\hline 6-Impression of staff and manager & 1.95 & 0.38 & 1.01 & 0.80 & 1.86 & 0.17 \\
\hline 7-Low services charges & $\mathbf{1 2 . 6 9}$ & $\mathbf{0 . 0 0}$ & 4.53 & 0.21 & 0.74 & 0.39 \\
\hline 8-Reputation and image of a bank & 4.00 & 0.14 & 2.84 & 0.42 & 0.02 & 0.88 \\
\hline 9-Parking facilities and convenience of location & 2.26 & 0.32 & 5.93 & 0.12 & $\mathbf{4 . 1 0}$ & $\mathbf{0 . 0 4}$ \\
\hline 10-Hours of operation & 2.99 & 0.23 & $\mathbf{9 . 3 6}$ & $\mathbf{0 . 0 3}$ & 3.13 & 0.08 \\
\hline 11-Online banking & 5.61 & 0.14 & 2.58 & 0.46 & 0.03 & 0.87 \\
\hline 12-Interior comforts ( like air conditioner) & 0.80 & 0.67 & 2.19 & 0.53 & 1.68 & 0.20 \\
\hline 13-Higher profits on account & 0.85 & 0.65 & $\mathbf{9 . 2 6}$ & $\mathbf{0 . 0 3}$ & 1.38 & 0.24 \\
\hline 14-External appearance of bank & 4.19 & 0.12 & 5.55 & 0.14 & 0.99 & 0.32 \\
\hline 15-Mass media advertisement & 1.43 & 0.49 & 4.25 & 0.24 & 3.62 & 0.06 \\
\hline 16-Recommendations by friends and relatives & 3.30 & 0.19 & 6.25 & 0.10 & 2.05 & 0.15 \\
\hline
\end{tabular}

In order to examine the relationship between the customers' preferences and other factors related to the respondents (qualification, age, gender) Chi-Square Test is applied. The test helps to find any significant differences among respondents in their perceptions towards bank selection criteria. The results are presented in table 3 .

The results show that the respondents, regardless of differences in qualification, age and gender, do not express any significant differences towards most of aspects of the bank selection criteria. The results, however, point out significant differences in the qualifications variable in case of knowledge about your requirements (7.17) and low service charges (12.69). In age variable, the reported chisquare figures indicate significant differences in case of higher profits on accounts (9.26) and hours of operations (9.36). Lastly, the gender variable, registers significant differences only in respect to convenience of location (4.10).

Overall majority aspects with significant differences carry overall lower rankings especially in case of age and gender variables. Thus, given the number of aspects offered to the respondents for their bank selection criteria, differences in the opinion, indicated in table 3 can be considered minimal.

The second part of the questionnaire covers customers' perception towards Islamic banking. It consists of seven questions as presented in table 4 . The first question asks respondents about their current level of knowledge towards Islamic banking. The results indicate that more than 50\% show limited knowledge about Islamic banking. Encouragingly, $70 \%$ of them show extreme willingness to know more about the principles and practices of Islamic banking. Perhaps it may be due to religious affiliation as all the respondents belong to Islam.
The next question asks the youngsters whether they understand various Islamic financial terms (Musharika, Mudarabah etc.) use in Islamic banking. The majority of the respondents either not understands the Islamic terms at all or has partial knowledge. These findings are similar to Gerrad and Cunningham (1997) [12] in case of Singapore, where though customers were aware of basic concepts of Islamic banking but were almost exclusively unaware of the meanings of specific terms like Musharika and Mudarabah etc.

Fourth question enquires about the need of Islamic banking in a country. Interestingly, the youngsters express strong need of Islamic banking. More then $70 \%$ of the respondents reply in favour of strong need of Islamic banking in a country. Further, almost the same percentages of respondents believe in the capabilities of Islamic banking in meeting the challenges of the future, as shown in question five.

The above outcomes are further supported by questions numbers six and seven where the youngsters show strong willingness to open accounts with Islamic banking regardless of profit returns. Good numbers of respondents are ready to scarify their profit returns for the development of Islamic banking in a country. However, profit returns are not fully ignorable in a competitive market. Nearly, $50 \%$ of the respondents urge that Islamic banking should offer returns parallel to conventional banking.

The overall results portray encouraging picture for Islamic banking as it has already attained high level customary confidence and satisfactions in Pakistan. Youngsters are quite interested to know more about Islamic banking and its financial products. The current scenario provides strong opportunity to Islamic bankers to attract this segment through effective media and publishing campaign. 
Table 4: Young Customers' Perceptions towards Islamic Banking

\begin{tabular}{|c|c|c|}
\hline Statement & $\mathbf{N}$ & $\%$ \\
\hline $\begin{array}{l}\text { 1- What is yours current level of awareness towards Islamic banking? } \\
\text { Not enough at all } \\
\text { Not enough } \\
\text { Just enough } \\
\text { Enough } \\
\text { More than enough }\end{array}$ & $\begin{array}{l}32 \\
32 \\
55 \\
38 \\
43\end{array}$ & $\begin{array}{l}16.0 \\
16.0 \\
27.5 \\
19.0 \\
21.5\end{array}$ \\
\hline $\begin{array}{l}\text { 2- DO you need more information towards Islamic banking? } \\
\text { Not required at all } \\
\text { Not required } \\
\text { Not sure } \\
\text { Required } \\
\text { Strongly required }\end{array}$ & $\begin{array}{c}9 \\
13 \\
20 \\
54 \\
104\end{array}$ & $\begin{array}{r}4.5 \\
6.5 \\
10.0 \\
27.0 \\
52.0\end{array}$ \\
\hline $\begin{array}{l}\text { 3- DO you understand Islamic banking terms (like Musharika, } \\
\text { Mudarbah)? } \\
\text { Not knowledge at all } \\
\text { Limited knowledge } \\
\text { Understand partially } \\
\text { Knowledgeable } \\
\text { Very knowledgeable }\end{array}$ & $\begin{array}{l}59 \\
32 \\
40 \\
33 \\
36\end{array}$ & $\begin{array}{l}29.5 \\
16.0 \\
20.0 \\
16.5 \\
18.0\end{array}$ \\
\hline $\begin{array}{l}\text { 4- Do we need Islamic banking? } \\
\text { Not required at all } \\
\text { Not required } \\
\text { Not sure } \\
\text { Required } \\
\text { Strongly required }\end{array}$ & $\begin{array}{c}5 \\
11 \\
22 \\
45 \\
117\end{array}$ & $\begin{array}{r}2.5 \\
5.5 \\
11.0 \\
22.5 \\
58.5\end{array}$ \\
\hline $\begin{array}{l}\text { 5- Can Islamic banking meet the challenges of the future? } \\
\text { No potential at all } \\
\text { No potential } \\
\text { Some potential } \\
\text { Good potential } \\
\text { A very good potential }\end{array}$ & $\begin{array}{l}20 \\
11 \\
33 \\
40 \\
96\end{array}$ & $\begin{array}{c}10.0 \\
5.5 \\
16.5 \\
20.0 \\
48.0\end{array}$ \\
\hline $\begin{array}{l}\text { 6- Should Islamic banks offer profit equal to conventional banks. } \\
\text { Absolutely untrue } \\
\text { Untrue } \\
\text { Not sure } \\
\text { True } \\
\text { Absolutely true }\end{array}$ & $\begin{array}{l}25 \\
29 \\
45 \\
46 \\
55\end{array}$ & $\begin{array}{l}12.5 \\
14.5 \\
22.5 \\
23.0 \\
27.5\end{array}$ \\
\hline $\begin{array}{l}\text { 7- Are you willing to open an account with Islamic bank regardless of } \\
\text { profit returns? } \\
\text { Strongly disagreed } \\
\text { Disagreed } \\
\text { Not sure } \\
\text { Agreed } \\
\text { Strongly agreed }\end{array}$ & $\begin{array}{l}12 \\
21 \\
32 \\
46 \\
89\end{array}$ & $\begin{array}{c}6.0 \\
10.5 \\
16.0 \\
23.0 \\
44.5\end{array}$ \\
\hline
\end{tabular}

\section{CONCLUSION}

The contribution of this study is twofold: theoretical contributions and practical implications. Theoretically, the study fills an important gap, that is, exploring bank selection criteria for potential young customers in case of
Pakistan. Therefore, the findings can be addable to the existing literature and can serve as a starting point on which future studies can be built. On practical side, the study identifies major factors that determine bank selection decisions among young customers. Such information can be helpful for the management in devising 
appropriate marketing strategies for reaching and attracting young customers.

Findings of this study reveal that young customers place more emphasis on factors like fast and efficient services, speed of transactions, impression and friendliness of bank personnel. They also give priority to factors such as 24hours availability of ATM service and low service charges. In short, young customers prefer dealing with a bank having efficient financial services handled by staff having friendly and good moral. Other interesting findings are that the young customers give least importance to high interest rates and investments on advertisements. They also want to rely on their own experiences in bank selection and give little importance to others recommendations.

The results also indicate that Islamic banking enjoys competitive advantage in terms of customers' confidence. Majority of respondents are satisfied with most aspects of the Islamic financial products and services. In fact, the main three reasons that received support can all be viewed as religious. They also believe in the capabilities and competitiveness of Islamic banks. Thus, Islamic banks have unprecedented young customers support, which can be utilized to explore new areas of investments.

The respondents are also quite familiar with the existence of Islamic banking in Pakistan. However, they show almost little awareness towards specific Islamic terms used (Mudarabah, Musharika etc.). It implies that Islamic banks operating in Pakistan need to educate their clients about the Islamic banking terminologies. Islamic banks should also translate Islamic terms into easy and understandable conventional languages.

\section{IMPLICATIONS}

This study provides guidelines to design marketing strategies for both Islamic and conventional banking systems based on customer-oriented approaches like "customer is boss" or "let the customer direct you" etc. Young customers in Pakistan perceive banks to be efficient and customer friendly. They focus more on the quality of services and E-banking instead of high profit and investment on advertisement. In case of Islamic banking, there are huge potential for Islamic financial instruments in Pakistan. Currently Islamic banking enjoys high level of satisfaction. The young customers show high level of willingness to open accounts with Islamic banks. The results lead towards the conclusion that there is already unprecedented young customers support for Islamic banking in a country, which can be also utilized to attract further customer.

\section{REFERENCES}

[1] Almossawi A (2001), "Bank selection criteria employed by college students in Bahrain", The International Journal of Bank Marketing, Volume 19 Number 3, pp.115-125.

[2] Edris A Thabet (1997)," The International Journal of Bank Marketing Volume: 15 pp. 126 - 133

[3] Nana Owusu-Frimpong (1999)," Patronage Behavior of Ghanaian Bank Customers", the International Journal of Bank Marketing, Volume: 17 -7 , pp. $335-342$

[4] Kaynak E and Odabasi Y (1991)," Commercial Bank Selection in Turkey", the International Journal of Bank Marketing, Volume: 9, Number: 4, pp. 86-97

[5] Radi C, (1989), "Attitudes, Behaviour, and Patronage Factors of Bank Customers towards Islamic Banks", the International Journal of Bank Marketing, Volume: 7 Number: 6, pp. 216- 229

[6] Burc Ülengin (1998), “Using hierarchical information integration to examine customer preferences in banking", The International Journal of Bank Marketing, Volume: 16 Number: 5, pp. $202-210$.

[7] Mosad Zineldin (1996), "Bank strategic positioning and some determinants of bank selection", The International Journal of Bank Marketing, Volume: 14, pp. 6-12

[8] Teik Oh Hai, (1999), “Consumer Bank Selection, Bank Product Utilization and Extent of Multiple Banking Relationships in a Central Business District The Case of Singapore", Power -Gen Library, Singapore.

[9] Anderson, F. W., C. Fomell, and D. R. Lehmann (1994), "Customer Satisfaction, Market Share, and Profitability: Findings from Sweden", Journal of Marketing, 58 (July), pp. 53-66

[10] Baldrigeplus (1999), "Customer Satisfaction loyalty", New Zealand, Macphe.http://www.bladrigeplus.com

[11] Jamal A, Ahmad J and Khalid K (1999), "Islamic Banking" the International Journal of Bank Marketing for the Financial Services Sector, Volume 17, Number 3.

[12] Philip Gerrard; J Barton Cunningham (1999)," The multiple banking behavior of Singaporeans" The International Journal of Bank Marketing, Volume: 17-1, pp. $26--35$ 
[13]Colgate, M (1997)," Personal Bankers and Relationship Marketing: A New Zealand Case Study”, Journal of Financial Services Marketing, Volume 2 (1), pp. 84-96.

[14] Fornell, C. (1992)," a National Customer Satisfaction Barometer: The Swedish Experience", Journal of Marketing, Volume 56 (January), pp. 6-21

[15]Fuad and Haq (1996)," Islamic banking”, Oxford University press, Karachi, Pakistan.
[16] Josée, Ruyter, Pascal (1998), “Investigating drivers of bank loyalty: the complex relationship between image, service quality and satisfaction", The International Journal of Bank Marketing, Volume: 16 Number: 7 pp. $276-286$

[17]Naser, K and Moutinho, L (1997)," Strategic marketing management: the case of Islamic bank", International Journal of Bank Marketing Volume 15 6, pp. 187-203. 